\title{
Cancer gene patent rights in doubt
}

\author{
The announcement that a second breast cancer gene had been found (and patents applied for) \\ little more than a year after it was mapped coincided with a report from a second group \\ who also claimed to have discovered the gene.
}

Reports late last December that two groups had independently identified and applied for patents on the second familial breast cancer gene (BRCA2) have set the stage for a potential transatlantic tussle over patent rights to the gene and any diagnostic or therapeutic applications that might stem from its discovery. The two rival groups - Myriad Genetics of Salt Lake City, Utah, and an international consortium of 41 researchers from the United Kingdom, the United States, Canada, France, Iceland and the Netherlands - have held preliminary discussions, and more meetings are expected, although both parties are remaining tight-lipped about the prospects for settling this matter out of court.

Myriad was the company that, in collaboration with researchers from the University of Utah and the US National Institutes of Health $(\mathrm{NIH})$, won the race to find the elusive $B R C A 1$ breast and ovarian cancer gene in 1994 (four years after it was mapped to chromosome 17). The company filed a US patent application on BRCA1, but soon after, found itself in hot water with NIH for failing to name two NIH researchers as coinventors. NIH filed a counter patent application, and a few months later, Myriad agreed to include the two researchers in a new filing.

News of the impending publication in Nature of a report on the finding of $B R C A 2$ by an international consortium, led by Michael R. Stratton of the UK Institute of Cancer Research in Sutton, Surrey, prompted Myriad to issue a onepage press release on 20 December that stated that the company had filed a US patent application on the "full sequence of a strong candidate for BRCA2." The release, issued the same day the consortium announced its discovery, also stated that Myriad claimed "all diagnostic and therapeutic uses of this newly discovered gene." Shares in the publicly traded company rose following the announcement, which a Myriad spokesperson says was made because of a responsibility to inform shareholders of its patent position with regard to $B R C A 2$.

The consortium's paper, on the other hand, was submitted to Nature on 5 December and published in the 21 December issue. CRC Technology, the technology transfer arm of the Cancer Research Campaign, one of the main sponsors of the consortium's work, filed a patent application for $B R C A 2$ in late November, claiming a partial gene sequence said to contain the entire coding region of the gene. Both groups' sequences are now in the public domain.

The discovery of $B R C A 2$ was aided by the public release on 23 November of sequence data from a 900-kilobase region of chromosome 13 (containing BRCA2) by researchers at the Sanger Centre in Cambridge and Washington University in St. Louis, Missouri. The sequence was an "enormous help," says Stratton, who emphasizes that even though he and his colleagues at the Institute of Cancer Research had collaborated with the Sanger Centre to produce a physical map of the region, they had "no prior access to that sequence." Stratton says that his group had been working on a fragment of the gene in which an abnormality had been identified in one of the breast cancer families before the release of the sequence data, but says it allowed his team "to identify additional large portions of the gene very quickly .... and to analyze those regions for additional mutations in other families," leading to quick confirmation of the gene.

Even though $B R C A 1$ and $B R C A 2$ have now been identified, testing is not expected to be straightforward. Nearly 100 different mutations have already been identified for $B R C A 1$, and it is too soon to tell whether $B R C A 2$ will exhibit a similar pattern, or whether the relative risk varies depending on the mutation. Moreover, a negative test result may not rule out the possibility that there are other (as yet unidentified) breast cancer susceptibility genes.

Consortium member and clinician Bruce A.J. Ponder of the CRC Human Cancer Genetics Research Group at Addenbrookes Hospital, Cambridge (who now gets about ten letters a week from patients or physicians saying, "Can I have the gene test?") worries about the effect that commercial pressures might have on who is tested. "The only way it would seem to me you're going to make money out of [genetic testing for breast cancer] is ... to do a lot of tests, and that implies that a lot of women may be tested whose family histories maybe aren't that strong."

Whether both parties are willing to resolve the current situation involving $B R C A 2$ without resorting to legal action is uncertain. Emma Plummer, a business manager at CRC Technology, says it is usual practice for the company to file a patent application in these circumstances, and that the chief motivation for doing so is to provide a means by which to "direct commercial exploitation" of the technology. A spokesperson for Myriad says that it is too soon to speculate on the likely outcome of any talks between it and CRC Technology, but adds that the company intends to file patents in other major commercial markets (the patent law in most countries allows a grace period of up to one year from the date of filing of the original application in which additional applications can be made).

If the talks fail, the issue of patenting is likely to be complicated by key differences between European and US patent law, particularly with regard to the rules of priority of invention. In contrast with the Unite States, where a "first-to-invent" rule is used and details of the patent application, such as the names of inventors, and dates of filing and of invention, are ordinarily kept confidential until a patent is granted, most other countries (including the United Kingdom) decide priority on a "first-to-file" basis. Added to this is the question of what constitutes a patentable invention - the full gene sequence or a partial sequence that includes the entire coding region and where disease-causing mutations have been identified? "While someone may be first to publish a partial sequence, that is different from filing the complete gene sequence," says the Myriad spokesperson.

The coming weeks and months will surely provide more grist for the media mill.

DIANE GERSHON 